\begin{abstract}
Олена Косигіна,
кандидат психологічних наук, доцент, завідувач кафедри педагогіки й андрагогіки

Комунального закладу «Житомирський обласний інститут післядипломної педагогічної освіти» Житомирської обласної ради

ORCID: 0000-0002-1895-4352

okos@ukr.net

Олександр Марченко,

аспірант кафедри педагогіки,

професійної освіти та управління освітніми закладами

Житомирського державного університету імені Івана Франка perspektiva-z@ukr.net

Олена Мірошниченко,

кандидат педагогічних наук, доцент,

доцент кафедри педагогіки,

професійної освіти та управління освітніми закладами Житомирського державного університету імені Івана Франка

ORCID: 0000-0002-5712-3752 perspektiva-z@ukr.net
\end{abstract}

\title{
ПСИХОПРОФІЛАКТИКА СТРЕСОВИХ ПЕРЕВАНТАЖЕНЬ У ПЕДАГОГІЧНИХ ПРАЦІВНИКІВ: ДОСВІД ЗАКЛАДІВ ОСВІТИ В УКРАЇНІ ТА ПОЛЬЩІ
}

У статті розкриваються особливості стресових перевантажень у педагогічних працівників у закладах освіти України та Польщі. Проаналізовано ефективність особистої поведінки та реакцій на дію стресорів учительської професіональної діяльності, а також засоби та прийоми для зняття стресової напруги у вчителів. Доведено, що негативним впливам стресових ситуацій протистоїть активна позиція особистості педагога та самостійність у прийнятті рішень. Продіагностовано 45 вчителів Житомирських закладів загальної середньої освіти на предмет наявності ознак професійного вигорання та доведена необхідність проведення тренінгової роботи щчодо особистісного зростання як засобу психопрофілактики психічних перевантажень у вчителів.

Ключові слова: типи стресових оцінок, первинна оцінка, вторинна оцінка, стресогенна подія, стресостійкість, самокорекція, індивідуальні програми психопрофілактики.

Olena Kosygina, Oleksander Marczenko, Olena Miroszniczenko. Psychoprofilaktyka przeciążeń stresowych u nauczycieli: doświadczenia placówek edukacyjnych na Ukrainie oraz w Polsce

$W$ artykule przedstawiono cechy przeciązenia stresem nauczycieli w placówkach edukacyjnych na Ukrainie $i$ w Polsce. Przeanalizowana jest efektywność osobistych zachowań $i$ reakcji na

stresory działalności zawodowej nauczyciela oraz narzędzia i techniki łagodzenia stresu u nauczycieli. Udowodniono, że negatywnym skutkom sytuacji stresowych przeciwstawia się aktywna pozycja osobowości nauczyciela i niezależność w podejmowaniu decyzji. U 45 nauczycieli liceów ogólnoksztatcacych w Żytomierzu zdiagnozowano oznaki wypalenia zawodowego oraz wykazano potrzebe prowadzenia pracy szkoleniowej w zakresie rozwoju osobistego jako środka psychoprofilaktyki przeciążenia psychicznego nauczycieli.

Stowa kluczowe: rodzaje ocen stresu, ocena pierwotna, ocena wtórna, zdarzenie stresowe, odporność na stres, autokorekta, indywidualne programy psychoprofilaktyki.

Olena Kosyhina, Olexandr Marchenko, Olena Miroshnychenko. Psychoprophylaxis of stress overload in teachers: experience of educational institutions in Ukraine and Poland The article reveals the features of stress overload in teachers in educational institutions of

(C) Олена Косигіна, Олександр Марченко, Олена Мірошниченко, 2020 
Олена Косигіна, Олександр Марченко, Олена Мірошниченко. Психопрофілактика стресових перевантажень у педагогічних працівників: досвід закладів освіти в Украӥні та Польщі

Ukraine and Poland. The relevance of the article is based on the fact that domestic and foreign scientists insist on the necessity to improve, change, carry out appropriate reforms in the system of modern science and education. Today, Ukrainian and Polish scholars are working to reach a consensus on the problems facing Polish and Ukrainian higher education. The effectiveness of personal behavior and reactions to the action of stressors of teaching professional activity is analyzed. The differentiation of types of stress assessments of teachers in unfavorable situations is outlined. The means and methods for relieving stress in teachers are analyzed. It is proved that the negative effects of stressful situations are opposed by the active position of the teacher's personality and independence in decision-making. 45 teachers of Zhytomyr secondary schools were diagnosed with signs of profession burnout. It has been found that about $60 \%$ of teachers have various signs of profession burnout. The stress factors that follow from the very functions of pedagogical activity and potentiate the development of frustration in teachers are highlighted. The necessity of conducting training work on personal growth as a means of psychoprophylaxis of mental overload in teachers has been proved. The experience of conducting such trainings at the Krakow University of Economics is taken into account. The newly created methodical manual of the authors of the article on conducting the training program is funded.

Keywords: types of stress assessments, primary assessment, secondary assessment, stressful event, stress resistance, self-correction, individual psychoprophylaxis programs.

Постановка проблеми в загальному вигляді та її зв'язок із важливими науковими й практичними завданнями. Стрімкий розвиток суспільства у XXI столітті передбачає інтеграцію, зближення, взаємопроникнення економічних й соціальних систем різних країн. Першочергово це стосується таких «близько поріднених» спільними історичними подіями країн, як Україна та Польща. Наші відносини з польським народом мають давню історію. Спільні слов'янські корені, подібність традицій, співзвучність мови та культури сприяли поглибленню цих відносин у різних галузях. Варто зазначити, що майже всі міжнародні наукові конференції, які відбуваються в Україні, проходять за участю польських науковців. Велика кількість українських шкіл, інститутів, університетів, інших закладів освіти співпрацюють з польськими, проводять спільні семінари, круглі столи, конференції тощо.

Але на сьогодні вітчизняні та іноземні вчені застерігають, що потрібні вдосконалення, зміни, проведення відповідних реформ у системі науки та освіти. Нині українські та польські науковці прагнуть досягнути консенсусу в розв'язанні тих проблем, котрі постали перед польською й українською вищою школою. Системи освіти наших країн потребують адаптації до нових, ускладнених форм функціонування в умовах тотального карантину, корекції надання освітніх послуг й збереження соматичного та психічного здоров'я педагогічних працівників.

Автори даної публікації перебували на стажуванні в закладах вищої освіти Польщі, зокрема, у 2018 році брали участь у польсько-українському проєкті проведення педагогічних тренінгів у Краківському економічному університеті, на якому порушувалися питання про діджиталізацію освітніх послуг та психопрофілактику стресових перевантажень у працівників освіти.

Психолого-педагогічні дослідження професійної діяльності педагогічних працівників свідчать про те, що вона тісно пов'язана з емоційно-вольовою сферою педагога, зумовлена не лише інтенсивними процесами міжособистісної взаємодії, а, насамперед, тим, що така діяльність є надзвичайно емоційно напруженою, виснажливою та стресогенною. Для того, щоб протистояти негативним впливам сучасного суспільства, фахівець будь-якої сфери, й педагог зокрема, має відповідати швидкоплинним стандартам якості життя соціуму. Так, виконавчий редактор американського журналу «Fortune», поляк за походженням, А. Лешинські, стверджує, що сучасному фахівцю необхідно мати такі якості: здатність вирішувати багаторівневі проблем, критичне мислення, креативність, уміння керувати людьми, взаємодія з підлеглими, емоційний інтелект, формування власної думки, 
клієнтоорієнтованість, вміння вести переговори, гнучкість розуму [3]. Такими якостями, на нашу думку, повинен володіти й педагог, щоб бути сучасним, сильним та ефективним.

Окреслення невирішених питань, порушених у статті. За результатами емпіричних даних С. Погольші, Л. Аболіна, І. Щербакова, С. Рогова та ін., для педагогів характерні найвищі показники за такими характеристиками: неврівноваженість та прагнення до стабільності, особисті проблеми та внутрішні конфлікти, моральні установки, авторитарність, фрустрація, виснаження та вигорання, а найбільш стресогенними факторами $\epsilon$ високий динамізм педагогічної діяльності та брак часу.

На думку О. Міхеєнка, здоров'я людини - це динамічний стан життєдіяльності людини, який характеризується здатністю організму до саморегуляції та самовідновлення. Автор вважає, що соматичне і психічне самопочуття цілком залежать від злагодженої взаємодії «елементів організму». Будь-яка неузгодженість процесів, що відбуваються в організмі, призводить до порушення гомеостазу й адаптаційних процесів, що призводить до професійного вигорання [7].

Г. Мешко та О. Мешко розглядали питання підготовки вчителів до збереження професійного здоров'я, у тому числі протистояння стресам у педагогічній діяльності [5]. У межах власного наукового дослідження вони визначили, що лише 7, 6\% сучасних українських педагогів почувають себе відносно здоровими з високим рівнем працездатності й стресостійкості. За даними авторів, 77,3\% педагогів відмічають у себе порушення в емоційній сфері та ознаки професійного виснаження [5, с. 207].

Водночас учителі зауважують, що не вміють протистояти стресам й долати негативний вплив стресових ситуацій. О.Санніков наголошує на тому, що негативним впливам стресових ситуацій протистоїть активна позиція особистості та самостійність у прийнятті рішень [10]. Г. Пирог дослідила, якими засобами та прийомами користуються майбутні педагоги для зняття стресової напруги, особливо після екзаменаційної сесії, яка, на думку авторки, $\epsilon$ серйозною стресогенною ситуацією. Такими прийомами є: прогулянки на свіжому повітрі (використовують близько 80 \% опитуваних), сон та спілкування з близькими (75\%); смачна іжа та фізична активність (50\%); на жаль, третина досліджуваних відволікається від стресу за допомогою негативних звичок - паління та вживання алкоголю [9, с.195].

Отже, на сьогодні низка проблем психопрофілактики стресових порушень у педагогів залишається невирішеними, що пов'язано, насамперед, особливостями роботи в умовах карантину як у нас, так і за кордоном.

Метою статті $\epsilon$ проаналізувати вплив стресових перевантажень на психоемоційний стан педагогічних працівників, представити методичні рекомендації психопрофілактики протистояння негативним впливам, враховуючи досвід закладів освіти України та Польщі.

Виклад основного матеріалу 3 обгрунтуванням отриманих наукових результатів. Сфера педагогічної діяльності належить до професій соціономічного типу, у яких провідну роль відіграє процес міжособистісної взаємодії. У процесі професійної взаємодії педагогічний працівник зустрічається з багатьма ситуаціями, які впливають на його внутрішній стан, поведінку, настрій, цінності та переконання. Це, у свою чергу, позначається на психоемоційному фоні, працездатності, мотивації та соціальній активності педагога. Коли особистість починає відчувати, що певна, нова для неї, ситуація являє фізичну або психічну загрозу (первинна оцінка), і коли усвідомлює, що не здатна в даний момент ефективно відреагувати на несприятливі події (вторинна оцінка), вона починає відчувати стрес. Вплив стресу та зростання відповідної тривожності у педагога можуть припинитися, якщо в його свідомості змінити значущість травмуючої ситуації в бік зменшення (нейтралізації) загрози.

Самостійно оцінити здатність й потенційні можливості щодо подолання екстремальної ситуації та опанування власних страхів педагогічний працівник зможе за умови достатньо розвиненої стресостійкості, яка корелює із властивостями центральної нервової системи, особливостями темпераменту та акцентуаціями характеру особистості. Також продуктивність адаптаційних процесів залежить від рівня розвиненості у педагога цілої 
Олена Косигіна, Олександр Марченко, Олена Мірошниченко. Психопрофілактика стресових перевантажень у педагогічних працівників: досвід закладів освіти в Украӥні та Польщчі

низки психологічних навичок, умінь, внутрішньої мотивації на засвоєння програм саморегуляції, зовнішньої фасилітації з боку референтно значущого оточення та, за необхідності, своєчасної якісної психологічної інтервенції.

Компетентністю й майстерністю в процесі адаптування до несприятливих ситуацій вважається здатність до самооцінювання ефективності особистої поведінки та реакцій на дію стресорів. В. Бойко диференціював типи стресових оцінок наступним чином:

1) особистісно значуща, травматична втрата когось або чогось (смерть, тривала розлука, втрата роботи, здоров'я тощо);

2) оцінка зовнішньої загрози, що вимагає від особистості значно більших ресурсів для подолання, ніж вона потенційно має;

3) оцінка рівня складності завдання (проблеми), що потребує вирішення «тут і зараз», оцінка власної відповідальності [1].

Отже, характеризуючи емоційне реагування педагогічного працівника на стрес, зазначимо, що його емоційність здатна як сприяти, так й перешкоджати адаптації до стресогенних подій. Саме емоції є первинним попереджувальним сигналом про загрозу, залишаючи в пам'яті відбитки про перенесені страждання й тривоги. У свою чергу, емоціїце регулятор поведінки, активності та опору, який фокусує увагу людини на реальній загрозі, яка може виникнути на ії життєвому шляху.

Для подолання психофізіологічного напруження, яке виникає як наслідок відчуття невизначеності у несприятливих для адаптації у соціумі умовах, педагогічний працівник потребує отримання нових знань щодо сутності проблеми, чинників ії виникнення, а також здатності запобігати загрозі як такій та уміння вирішувати проблеми (завдання). Новостворена ситуація може викликати відчуття безпорадності, панічні реакції, коли особистість відчуває себе неспроможною адаптувати до стресової ситуації знайомі, звичні поведінкові алгоритми, що, у свою чергу, викликає розвиток дистресу.

Успішність оволодіння стресом залежить від особливостей самокорекиії, а саме: здатності педагога моделювати подальші події, здатності до самоаналізу та самоконтролю, знаходження потрібної інформації, прийняття допомоги від фахівців. Травматичність події, що відбувається, визначається збігом реального змісту загрозливих обставин 3 індивідуальним сприйняттям особистістю змісту та ступеню загрози та особистої шкоди, $\mathrm{i}$, як наслідок, - педагогічний працівник відчуває стан стресу, відчуває психоемоційне вигорання.

Враховуючи певні психофізіологічні особливості особистості, що визначаються властивостями нервової системи, темпераменту, акцентуацій характеру, спадковими впливами, можна спрогнозувати законономірні типи поведінкових реакцій в кризових ситуаціях відповідно до рівня стресостійкості особистості та здатності до продуктивної адаптації у стресі. Таким чином, за однакових зовнішніх обставин, при подібних за інтенсивністю стресорах, одні з педагогів трансформують стрес у ситуацію подальшого власного особистісного розвитку, набуваючи нових знань, навичок опору несприятливим умовам та реалізації особистісно орієнтованої взаємодії у професійній діяльності; інші ж перетворюються у «жертв обставин», відчувають себе виснаженими, неспроможними продуктивно працювати, спілкуватись, починають хворіти.

У звичних обставинах, за наявності достатніх знань й самомотивації, поведінка стресостійких та стресонестійких індивідів може зовні майже не відрізнятися й бути однаково успішною. Але, як тільки ускладнюються умови діяльності, зокрема підвищується рівень зовнішніх вимог та необхідність особистої відповідальності, істотно ущільнюється термін виконання тих чи інших завдань, то з'являється дефіцит часу (що поєднується 3 екстремальними зовнішніми чинниками) - індивідуальні відмінності в стресостійкості особистості стають головною умовою успішного опанування подіями й збереження потрібного рівня працездатності та поведінкової ефективності. 
Яскравим прикладом цього може слугувати поведінка педагогів у період карантину, яку ми спостерігаємо в динаміці: у стресостійких педагогічних працівників адаптаційний синдром створює перманентний стан робочої мобілізації, легке психофізіологічне збудження, сприяє зростанню темпу психічної діяльності, вольовій самоорганізації, а разом 3 цим - показники ефективності та успішності професійної діяльності зберігаються або навіть підвищуються. Стресонестійкі учителі в подібній ситуації стають ще більш емоційно вразливими, у них зростає рівень особистісної та ситуативної тривожності, відмічається субдепресивний стан, порушується сон, змінюється харчова поведінка, з'являються фізіологічні симптоми (головний біль, пітливість, тремтіння рук, порушення на рівні серцево-судинної системи, шлунково-кишкового тракту). Усе це негативно позначається на пізнавальній активності: послаблюється рівень уваги, з'являються «провали» у пам'яті, відбувається або «скакання» думок, або їх загальмованість, унаслідок чого знижується ефективність професійної діяльності, якість життя педагогічного працівника.

У стресогенних ситуаціях актуалізується проблема необхідності самокорекиії педагогом емоційно напружених станів та неадекватних реакцій, спричинених стресом у екстремальних та кризових ситуаціях; розроблення індивідуальних програм психопрофілактики негативних наслідків впливу несприятливих подій як на психічне, так i на соматичне здоров'я педагогічних працівників. Слід зазначити, що індивідуальні реакиіі на стресові навантаження визначаються такими психофізіологічними чинниками: природними властивостями нервової системи, темпераменту та акцентуації характеру особистості; адаптаційними можливостями організму, що спричинені природною здатністю до адаптації шляхом вегетативної саморегуляції, впливом навколишнього середовища та загальним станом здоров'я людини.

Відповідно до визначених вище розбіжностей, педагогічні працівники можуть належати до однієї із двох полярних груп (стресостійкі та стресонестійкі особистості).

До стресостійкого типу належать особистості зі стійкою нервовою системою, вищим за середній та високим рівнем працездатності, витривалості, концентрації уваги, стійкості до впливу будь-яких перешкод та несприятливих життєвих факторів (звуків, температури, відволікаючих подразників, життєвих та професійних викликів, ситуацій невизначеності). У кризових ситуаціях такі педагогічні працівники беруть на себе відповідальність за прийняття професійних рішень, організацію діяльності колективу в нових умовах, зберігають стійку (сталу) адекватну орієнтацію в ситуації та переживають особистісну кризу без втрати життєвих позицій. Такі особистості краще справляються із незвичними та екстремальними умовами роботи, зберігаючи при цьому високу продуктивність та цілеспрямованість діяльності. Педагоги з високим рівнем стресостійкості здатні залишатися врівноваженими, спокійними, раціонально приймають рішення, їхня поведінка $\epsilon$ вмотивованою та відповідає зовнішнім стимулам й викликам.

Проте людям із таким психотипом притаманні низький рівень емоційної чутливості, сенситивності, що нерідко заважає розвиненості тонких форм й відтінків сприймання та відчуття оточуючого світу, інших людей та загрозливої ситуації. Виражений природний потенціал активності виявляється у стресостійких педагогічних працівників, з одного боку, в ініціативності, зацікавленості та включеності в соціальну взаємодію, а з іншого - це нерідко саме той тип людей, які працюють на повне виснаження, знесилення, ігнорують здоровий спосіб життя та раціональний режим праці й відпочинку.

Так, за результатами анкетування вчителів, які проходили курси підвищення кваліфікації в Житомирському обласному інституті післядипломної педагогічної освіти, ми встановили, що більша частина їх робочого дня $(66,2 \%)$ протікає в напружених обставинах. Найбільш напруженими $є$ ситуації проведення занять у нових умовах дистанційного навчання, спілкування вчителя з учнями «на відстані», організація та проведення позакласних освітніх заходів, керівництво самостійною роботою школярів. Більшість респондентів указують на хвилювання, що не вдається знизити навіть вольовими зусиллями, розгубленість, нервозність 
Олена Косигіна, Олександр Марченко, Олена Мірошниченко. Психопрофілактика стресових перевантажень у педагогічних працівників: досвід закладів освіти в Украӥні та Польщчі

та погіршення самопочуття. 3 них - $50 \%$ опитаних указали на погіршення результатів їх діяльності, $35 \%$ - на зниження працездатності, а $20 \%$ - на виникнення нехарактерних помилок (технічні помилки та ін.).

За нашими даними, до групи стресонестійких належать педагоги зі слабкою нервовою системою, що демонструють невисокий рівень соціальної активності, працездатності та витривалості, підвищену втомлюваність, зниження рівня уваги та нездатність протистояти зовнішнім подразникам у процесі професійної діяльності. Водночас вони впевнено й успішно працюють у спокійних, звичних умовах; якісно виконують чітко алгоритмізовані види діяльності; спокійно працюють в умовах, які не вимагають за короткий термін переформатовувати звичні технології та методи роботи, відреагувати терміново на нові умови (як це необхідно було зробити, наприклад, під час переходу на дистанційний формат в освітній діяльності).

Особливостями стресонестійких осіб є їх висока сенсорна та емоційна чутливість, тонке реагування на внутрішні переживання та події в оточуючому середовищі; емпатійність, схильність до самоаналізу та рефлексії, яскрава вразливість. Саме притаманна їм схильність до духовного та психологічного розвитку спонукає таких педагогічних працівників до створення індивідуальних траєкторій психофізичного та світоглядного зростання. Проте в реальному житті вони не завжди спроможні забезпечити ефективність діяльності та міжособистісної взаємодії, самостійно опанувати стресовий стан, зменшити рівень тривоги та позбавитися страхів.

Однією 3 поширених форм психологічного захисту особистості від інформаційних стресових перевантажень стала міжособистісна відстороненість, втрата інтересу до інших людей, емоційна невключеність у події та уникнення відповідальності у зв'язку 3 необхідністю прийняття рішень. Такий прояв психологічного захисту може усвідомлюватися або не усвідомлюватися самим педагогом, але він поступово призводить до стану хронічної емоційної напруженості, відсторонення від вирішення конкретних життєвих проблем, професійних деформацій особистості, зниження професійної та соціальної активності. Психосоматичними наслідками такої дезадаптивної поведінки стають інсульт, інфаркт, гіпертонічна хвороба, захворювання шлунково-кишкового тракту, алергічні та інші проблеми зі здоров'ям.

К. Маслач деталізувала це поняття, окресливши його синдромом фізичного та емоційного виснаження, що складається 3 розвитку негативної самооцінки, негативного ставлення до роботи та втрати розуміння співчуття щодо клієнтів. Вона підкреслює, що «професійне вигорання» - це не втрата творчого потенціалу, не реакція на нудьгу, а скоріше емоційне виснаження, що виникає на фоні стресу, викликаного міжособистісним спілкуванням [4]. К. Маслач розглядає синдром «професійного вигорання» як трьохкомпонентну систему, яка складається 3 емоційного виснаження, деперсоналізації та редукції власних особистісних прагнень. Емоційне виснаження - основна складова професійного вигорання й проявляється у зниженні емоційного фону, байдужості або емоційній перенасиченості. Деперсоналізація проявляється в деформації стосунків 3 іншими людьми. Це може бути підвищення залежності від інших або підвищення негативізму, цинічності установок й почуттів. Редукція особистих досягнень може проявлятися або в тенденції до негативного оцінювання себе, своїх професійних досягнень і успіхів, негативізмі відносно службових досягнень й можливостей, або ж обмеженні своїх можливостей, обов'язків щодо інших.

Наші дані свідчать про те, що на кожному етапі педагогічної діяльності є свої особливості, які впливають на психоемоційний стан учителя. Перші 5 років у школі - це час адаптації молодого працівника до умов роботи; 6-7 років - формування професійної позиції, підвищення професійної значущості; для учителя з 11-15-річним стажем роботи характерна «педагогічна криза», яка носить суперечність між бажанням щось уміти й можливостями педагога; 16-20 років - період, пов'язаний із «кризою середини життя», коли підбивають попередні підсумки. Найпродуктивнішим вважаємо період у вчителів 3 досвідом 21-25 років. 
Цьому сприяють наступні фактори: сформованість професійно важливих рис; особистісна сфера життя (власні діти вже виросли, а тому вони повністю зосереджуються на роботі); авторитет й повага 3 боку оточуючих тощо. Для педагогів зі стажем понад 25 років характерне особливе сприйняття контролю за своєю діяльністю, яке залежить від біологічного старіння, психоемоційного напруження, професійного старіння (небажання опановувати нові методи роботи, несприйняття інновацій в освіті).

Г. Никифоров [8] виділив низку чинників, що зумовлюють виникнення та розвиток емоційного вигорання: особистісні (схильність до інтроверсії, реактивність, твердість, авторитарність, агресивність, низький рівень самоповаги й самооцінки тощо); статуснорольові (рольовий конфлікт, рольова невизначеність, незадоволеність професійним й особистісним зростанням, низький соціальний статус, рольові поведінкові стереотипи, відторгненість у референтній групі, негативні статево рольові (гендерні) установки тощо); професійно-організаційні (несправедливість взаємин в організації, відсутність корпоративної згуртованості, слабка організаційна культура, внутрішньо організаційні конфлікти, дефіцит адміністративної, соціальної та професійної підтримки, відсутність свободи планування, жорсткий контроль, відстороненість від прийняття рішень тощо); екзистениійні (нереалізовані життєві й професійні очікування, незадоволеність самоактуалізацією, досягнутими результатами, розчарування в інших людях чи в обраній професії, знецінювання й втрата сенсу своїх зусиль, переживання самотності, відчуття безглуздості активної діяльності й життя взагалі тощо).

3 метою дослідження проблеми емоційного вигорання у вчителів нами було проведено дослідження за методикою «Діагностика рівня емоційного вигорання» В. Бойка в одному із закладів загальної середньої освіти м. Житомира. Нижче представлені результати визначення рівнів емоційного вигорання у педагогів школи (загальна кількість досліджуваних - 45 вчителів, 3 них 39 - жінок, 6 - чоловіків ) залежно від стажу роботи (див. табл. 1).

Таблиияя 1

Рівні емоційного вигорання педагогів (у \%)

\begin{tabular}{|c|c|c|c|c|c|c|c|c|c|}
\hline \multirow[b]{2}{*}{$\begin{array}{c}\text { Стаж } \\
\text { роботи }\end{array}$} & \multicolumn{3}{|c|}{ Напруження } & \multicolumn{3}{|c|}{ Резистенція } & \multicolumn{3}{|c|}{ Виснаження } \\
\hline & 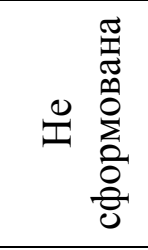 & 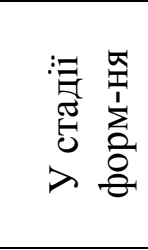 & 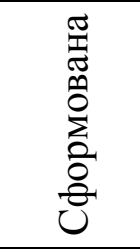 & 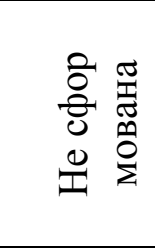 & 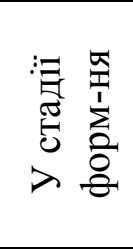 & 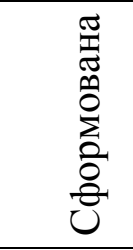 & 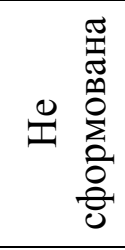 & 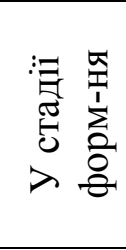 & 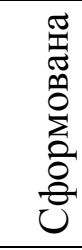 \\
\hline $\begin{array}{l}\text { До } \\
\text { 5-ти рр. }\end{array}$ & $62,2 \%$ & $37,7 \%$ & $0 \%$ & $100 \%$ & $0 \%$ & $0 \%$ & $100 \%$ & $0 \%$ & $0 \%$ \\
\hline $6-10 \mathrm{pp}$ & $100 \%$ & $0 \%$ & $0 \%$ & $57,7 \%$ & $0 \%$ & $42,3 \%$ & $100 \%$ & $0 \%$ & $0 \%$ \\
\hline $11-15 \mathrm{pp}$. & $100 \%$ & $0 \%$ & $0 \%$ & $0 \%$ & $40,0 \%$ & $60,0 \%$ & $100 \%$ & $0 \%$ & $0 \%$ \\
\hline $\begin{array}{l}\text { Більш } \\
\text { 15-ти pp. }\end{array}$ & $77,8 \%$ & $0 \%$ & $22,2 \%$ & $17,8 \%$ & $82,2 \%$ & $0 \%$ & $100 \%$ & $0 \%$ & $0 \%$ \\
\hline
\end{tabular}

Аналізуючи результати, зауважуємо, що у педагогічних працівників спостерігається повна або часткова сформованість фаз професійного вигорання. Як видно з таблиці, найбільший відсоток (82,2 \%) припадає на фазу «резистенції», яка знаходиться у стадії формування. Сформована фаза «резистенції» спостерігається у 26,6 \% досліджуваних. Це говорить про те, що фактичний опір стресу, що зростає, починається 3 моменту появи тривожного напруження. Людина усвідомлено або несвідомо прагне до психологічного комфорту, 
намагається знизити тиск зовнішніх обставин за допомогою наявних у іiі розпорядженні засобів, що говорить про необхідність профілактики та корекції психоемоційного стану.

Висновки. Проаналізувавши отримані дані та порівнявши наші результати 3 дослідженнями польських колег 3 Краківського економічного інституту (які практично збігаються 3 нашими), ми дійшли висновку про необхідність проведення тренінгів для психопрофілактики та попередження стресових перевантажень у педагогічних працівників. Для цього нами був розроблений науково-методичний посібник за такою програмою (один 3 авторів даної статті - автор посібника, інший - рецензент) [6]. У посібнику представлені акмеологічні засади проведення тренінгів для педагогічних працівників і психологопедагогічні тренінги, які не тільки допомагають формуванню позитивних професійних якостей, а й сприяють попередженню та подоланню негативних наслідків емоційного вигорання.

\section{Список використаних джерел та літератури}

1. Бойко В. В. Синдром «эмоционального выгорания» в профессиональном общении. 2-е изд. СанктПетербург, 2001. 434 с.

2. Сгорова Є. Феномен емоційного вигорання та його прояви в професійній діяльності педагогічних працівників закладів профтехосвіти. Педагогіка і психологія. Вісник АПН. 2010. № 4. С. 66-73.

3. Лашински A. Uber: инсайдерская история мирового господства. Москва, 2019. 288 с.

4. Maslach C. Burnout: A social psychological analysis. In The Burnout syndrome ed.J.W.Jones, pp. 30-53, 1982.

5. Мешко Г. М., Мешко О. І. Підготовка майбутніх учителів до збереження і зміцнення професійного здоров'я. Development and modernization of social sciences: experience of Poland and prospects of Ukraine: Collective monograph. Vol. 2. Lublin, 2017. 336 p. C. 206-223.

6. Мірошниченко О. А. Акмеологічні засади проведення психолого-педагогічних тренінгів для дорослих. Житомир, 2020. 360 с.

7. Міхеєнко О. І. Конкретизація сутності поняття «здоров'я»як методологічне підгрунтя практики оздоровлення організму людини. Педагогіка, психологія та медико-біологічні проблеми фізичного виховання і спорту. 2013. № 2. С. 42-46.

8. Психология здоровья: Учебник для вузов. Санкт-Петербург: Питер, 2006. 607 с.

9. Пирог Г. В. Психологічні особливості та проблеми професійного становлення студентівпсихологів. Особистісне зростання в умовах трансформації сучасного суспільства: монографія. Житомир, 2020. С.192-200.

10. Sannikov O. Information system operator: the structure and components of personal choice. Наука і освіта: журнал науково-практичний: Психологія. № 7/CXXXVIII, 2016. Одеса. С. 133-143.

\section{References (translated \& transliterated)}

1. Bojko, V. (2001). Sindrom «emocional'nogo vygoraniya»v professional'nom obshchenii [Syndrome of «emotional burnout» in professional communication]. 2-e izd. Sankt-Peterburg. 434 p. [in Russian].

2. Jegorova, Je. (2010). Fenomen emocijnogo vigorannya ta jogo proyavi v profesijnij diyal'nosti pedagogichnih pracivnikiv zakladiv proftekhosviti [The phenomenon of emotional burnout and its manifestations in the professional activity of pedagogical workers of vocational education institutions]. Pedagogika i psihologiya. Visnik APN. № 4. Pp.66-73 [in Ukrainian].

3. Lashinski, A. (2019). Uber: insajderskaya istoriya mirovogo gospodstva [Uber: an insider story of world domination]. Moskva. 288 p. [in Russian].

4. Maslach, C. (1982). Burnout: A social psychological analysis. In The Burnout syndrome ed.J.W.Jones, Pp. 30-53 [in English].

5. Meshko, G. \& Meshko, O. (2017). Pidgotovka majbutnih uchiteliv do zberezhennya i zmicnennya profesijnogo zdorov'ya [Preparing future teachers to maintain and enhance professional health]. Development and modernization of social sciences: experience of Poland and prospects of Ukraine: Collective monograph. Vol. 2. Lublin, 336 p. Pp.206-223 [in Ukrainian].

6. Miroshnichenko, O. (2020). Akmeologichni zasadi provedennya psihologo-pedagogichnih treningiv dlya doroslih. [Acmeological principles of psychological and pedagogical training for adults]. - Zhytomyr. 360 p. [in Ukrainian]. 
7. Miheenko, O. (2013). Konkretizaciya sutnosti ponyattya «zdorov'ya» yak metodologichne pidrruntya praktiki ozdorovlennya organizmu lyudini [Concretization of the essence of the concept of "health" as a methodological basis for the practice of healing the human body]. Pedagogika, psihologiya ta medikobiologichni problemi fizichnogo vihovannya i sportu. № 2. Pp. 42-46 [in Ukrainian].

8. Psihologiya zdorov'ya: Uchebnik dlya vuzov (2006). [Psychology of health: A textbook for universities] / Pod red. G. S. Nikiforova. Sankt-Peterburg. 607 p. [in Russian].

9. Pirog, G. (2020). Psihologichni osoblivosti ta problemi profesijnogo stanovlennya studentiv-psihologiv [Psychological features and problems of professional development of students-psychologists]. Osobistisne zrostannya $v$ umovah transformaciï suchasnogo suspil'stva: monografiya. - Zhytomir. Pp.192-200 [in Ukrainian].

10. Sannikov, O. (2016). Information system operator: the structure and components of personal choice. Nauka i osvita, 7, Pp.133-143 [in English].

Статтю отримано $28.10 .2020 \mathrm{p}$.

Прийнято до друку 18.11.2020 p. 